\title{
A Simplified ArcGIS Approach for Landslides Risk Assessment in the Province of Bergamo
}

\author{
Barbara Marana \\ Department of Engineering and Applied Science, University of Bergamo, Bergamo, Italy \\ Email: barbara.marana@unibg.it
}

How to cite this paper: Marana, B. (2017) A Simplified ArcGIS Approach for Landslides Risk Assessment in the Province of Bergamo. Journal of Geographic Information System, 9, 699-716.

https://doi.org/10.4236/jgis.2017.96044

Received: October 27, 2017

Accepted: December 2, 2017

Published: December 5, 2017

Copyright $\odot 2017$ by author and Scientific Research Publishing Inc. This work is licensed under the Creative Commons Attribution-NonCommercial International License (CC BY-NC 4.0).

http://creativecommons.org/licenses/by-nc/4.0/

\begin{abstract}
The paper describes a simplified GIS approach, for landslides risk assessment in the Province of Bergamo, developed for a GIS degree thesis at the faculty of Engineering of the University of Bergamo. The subject has been and still is largely studied by many researchers with the aid of rigorous mathematical/statistical analysis tools. This work follows some procedures carried out by other studies, but at the end it has been decided to adopt a simple, fast and not rigorous way to find a solution. A following analysis, on the higher risk areas identified, has also been performed to test their reliability, allowing achieving satisfactory results. It has been planned to study the risk model more thoroughly, by taking into account other triggering causes for landslide susceptibility and to try also a rigorous approach, so as to get a better idea of the results achieved so far and how to improve them.
\end{abstract}

\section{Keywords}

Landslides, Province of Bergamo, Triggering Factors, Risk Assessment

Evaluation, GIS Analysis, Higher Risk Zones Identification and Test

\section{Introduction}

Landslides analysis is a subject which has been studied for a long time and it is still of great interest nowadays. These terrible and fatal phenomena depend on both natural and human causes, such as climate changing, glaciers melting, soil disruption, earthquakes, etc. (Figure 1).

Recently, on the $23^{\text {th }}$ of August, a new event happened in Switzerland, in Val Bregaglia, in the Grigioni canton, very close to the Italian province of Sondrio (Figure 2 and Figure 3) [2] [3] [4] [5] [6]: a huge detritus mass has swept away many old stables, chalets and houses and about 100 inhabitants have been moved to safer places for precautionary measures. Luckily nobody living there 


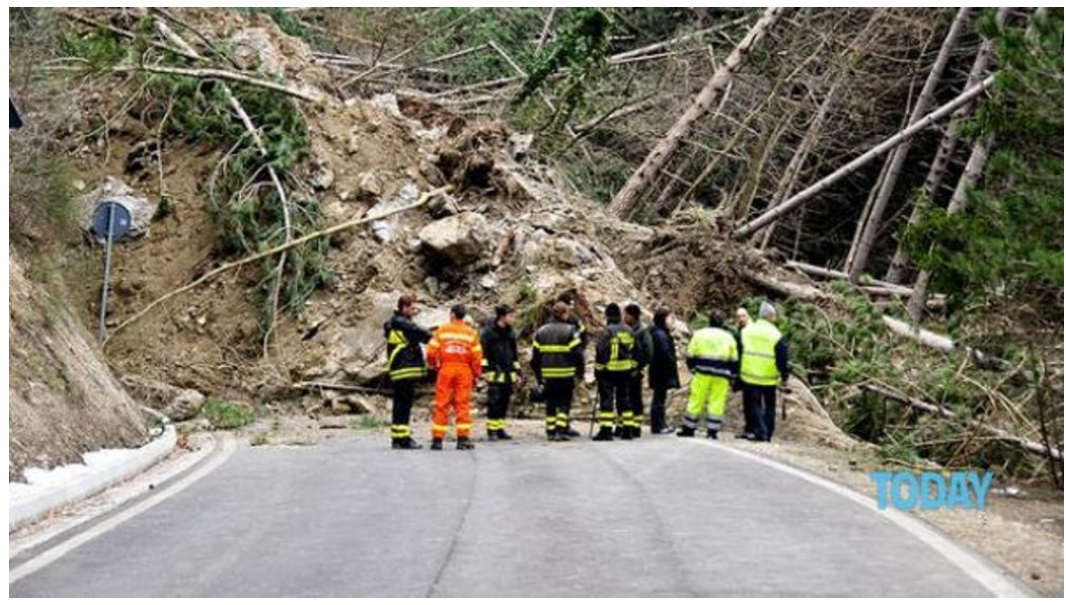

Figure 1. A landslide scenario [1].
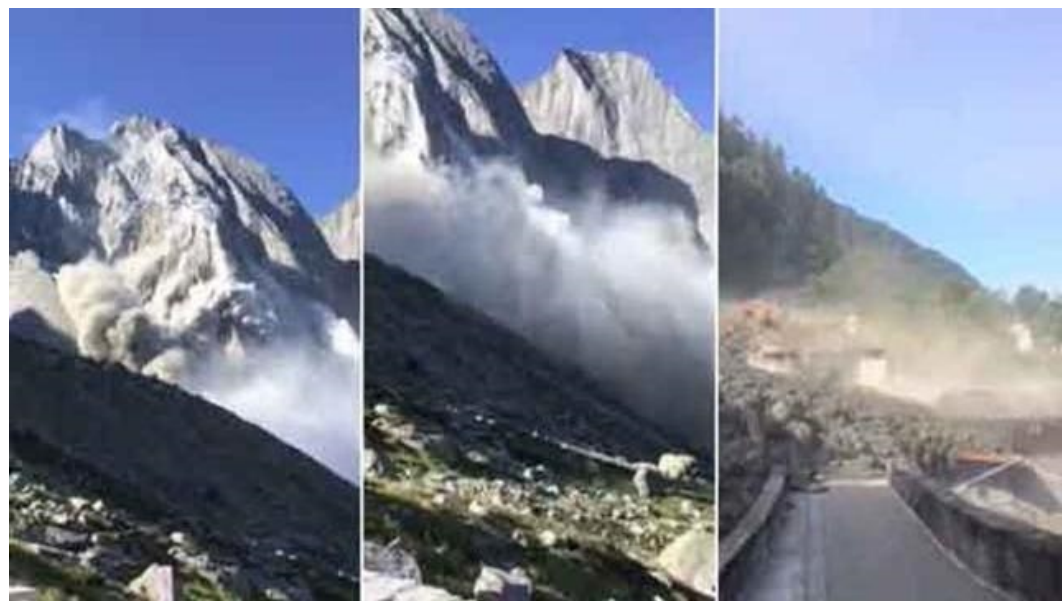

Figure 2. The Alps Pizzo Cengalo landslide in Val Bregaglia [2].

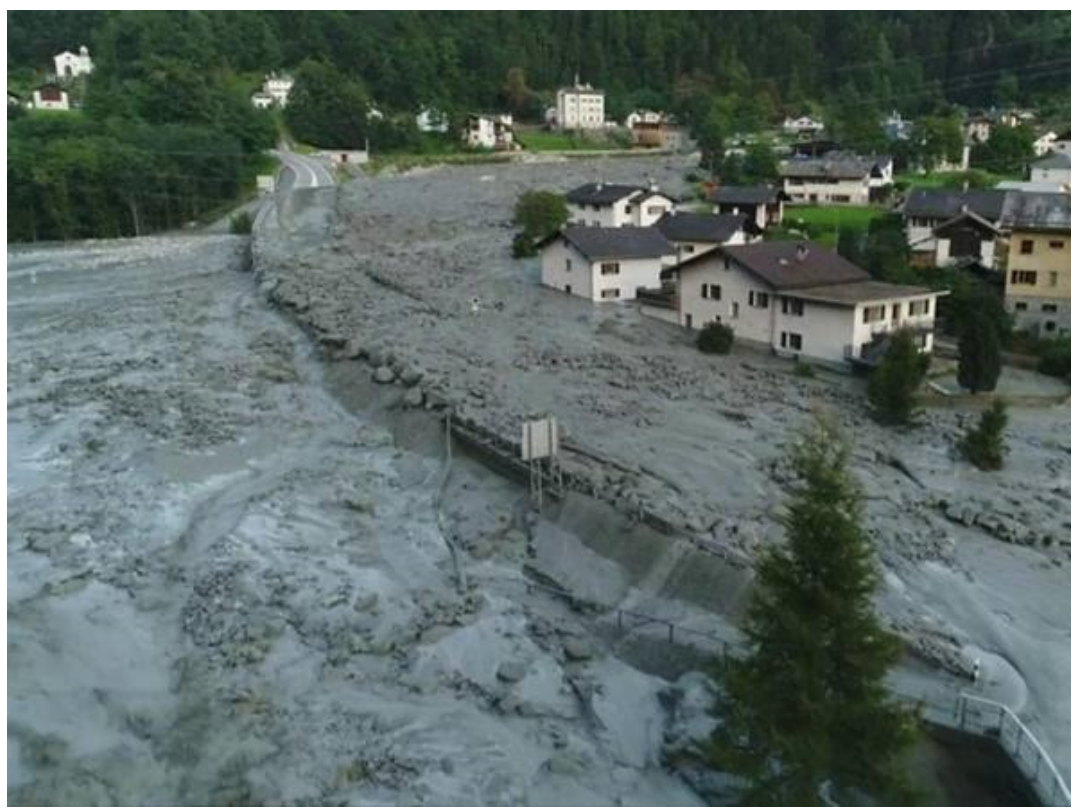

Figure 3. The Val Bregaglia landslide [2]. 
has been injured, but water and electricity have been interrupted and a main street, used mostly by people living in Italy and moving to work in Switzerland daily (the so called Frontalieri), has been closed and later opened only in a one-way direction. Some hikers were reported missing at first, but in the end they have been found safe and already back in Italy.

The very bad news [7] [8] has been given after some time, when 8 alpinists, of different nationalities, have been at first reported missing in the Pizzo Cengalo area, but later their search has been interrupted; in fact, it has been estimated, with high probability, that the huge detritus mass of soil and rocks, detached from that mountain, carrying downwards more than 4 million $\mathrm{m}^{3}$ of rocks at a $250 \mathrm{~km} / \mathrm{h}$ speed, must have swept them away, this way preventing their search and possible retrieval.

Human loss, structures and infrastructures damages, the shock and fear for people, all these are well known sad problems related to landslides, and also the after effects need to be considered, like pollution of rivers and lakes caused by the detritus mass fast flowing in them.

In fact, as a consequence of the just described event in Val Bregaglia, a river has been classified as "dead": The Mera river, flowing from Switzerland to Italy, has been invaded by the detritus mass and its ecosystem and fishes have been compromised, since completely stifled by the rock mass, fast destroying all forms of life [9].

\section{Landslides}

Landslides belong to the gravitationally driven natural hazards (like avalanches) and they depend on many causes: geological, anthropogenic, hydrological, morphological and environmental. For this reason, the phenomenon is quite complex, but needs to be seriously studied because of the huge damages to people, villages, environment and infrastructures.

Many researchers have been and are nowadays studying different solutions and risk assessment models. As a matter of fact, in literature it's possible to find many papers about different experiences developed with the aid of rigorous mathematical/statistical techniques [10]-[24].

Landslides in Italy are not unusual, in fact, just in 2010, 88 landslide events have caused many dead, injured and evacuated people [25].

The Superior Institute for Protection and Environmental Research (ISPRA) has stated that Italy is quite a fragile country and landslide events have been recorded in about $70.5 \%$ of its commons. According to the mapping work realized by the IFFI project (Inventory of Landslides in Italy), starting from 1116, up to 2006, more than 480.000 landslides occurred in Italy, quite a large number if compared to the corresponding amount in all Europe of 700.000 [25] [26]. The causes are very heterogeneous: abundant rainfalls, earthquakes, but also anthropic factors like deforestation and illegal development. According to the data published by ISPRA, up to 2016 , about $23.000 \mathrm{~km}^{2}$ of soil have been depleted in Italy (nearly $7.6 \%$ of the nation territory). 
The experience here described has been developed for the territory of the Province of Bergamo [27] (Figure 4), which covers an area of about $2750 \mathrm{~km}^{2}$, located mostly in the central part of the Lombardy mountainous region, with Alps and hills, and in a little part of the Lombardy Plain. Its morphology (Figure 5) well reflects this heterogeneity, since it is $64 \%$ mountains, $12 \%$ hills and $24 \%$ plane.

The climate is moderate subcontinental, but it is much diversified, because of the terrain morphology just described:

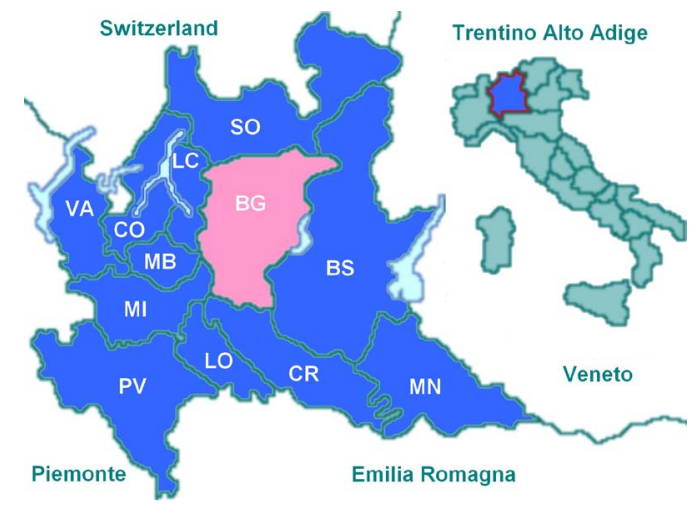

Figure 4. The province of Bergamo in northern Italy [30].

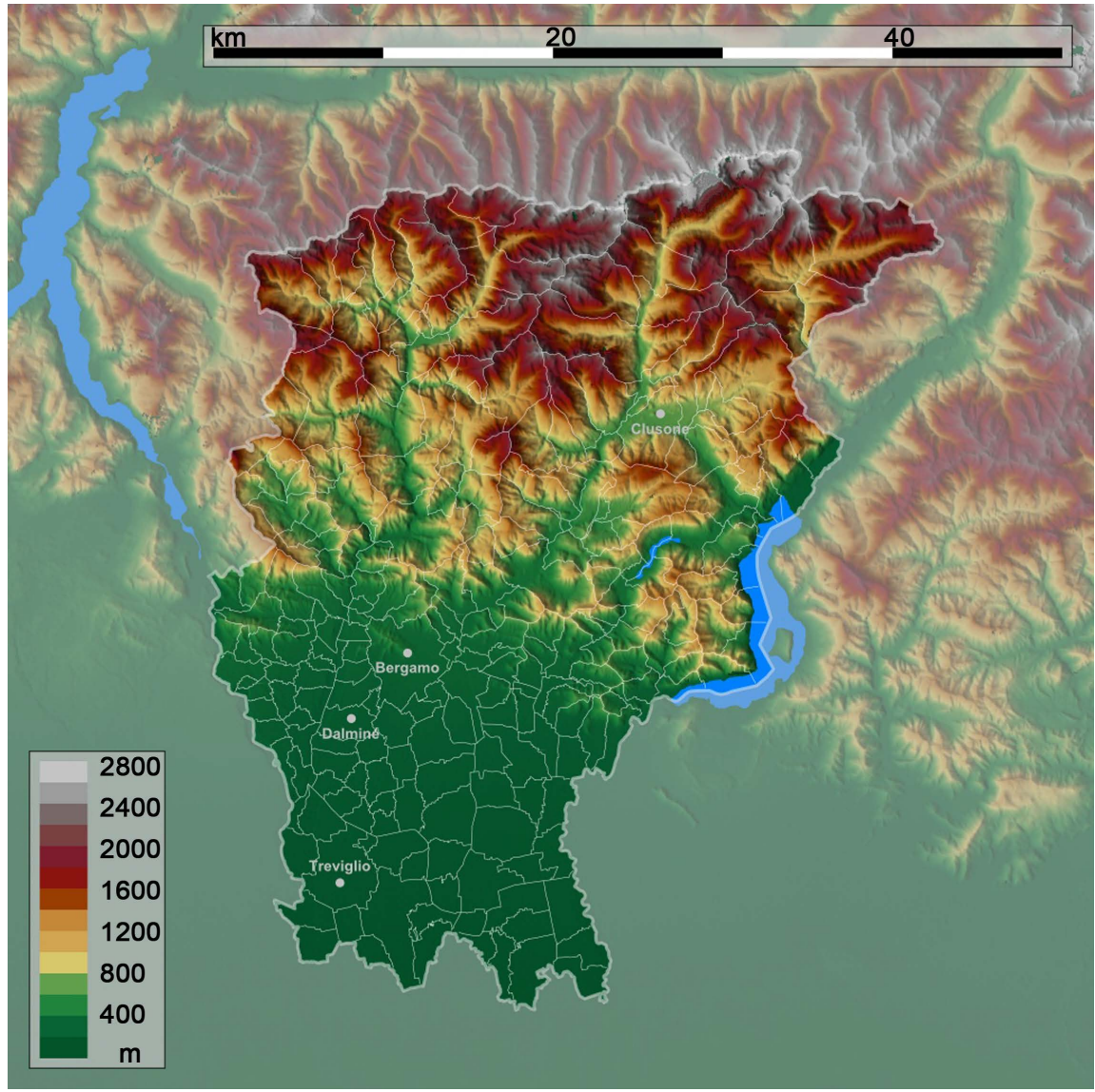

Figure 5. The province of Bergamo morphology [31]. 
- plain area: very hot and humid in summer, long and cold winter, but without abundant rainfalls; during the year the temperature range is high and fog can be very intensive;

- hill and mountain area: alpine climate with fresh summer with abundant rain and long, cold winter with little rain.

The choice to select this test area is that our University has many students coming from different places, but most of them live in the Province of Bergamo, above all in the town of Bergamo and also in the surrounding valleys; these case studies are then a good opportunity for them to get a better knowledge of the place in where they live and of the great problems connected to this territory.

The Province of Bergamo has been working on the landslide issue for a long time, since its territory is frequently vulnerable to these events [28] [29].

\section{The Project}

According to what said before, in this study the landslides triggering factors, taken into account for landslide risk assessment, have been divided in five main categories here described.

- Morphological: the description of the terrain morphology through elevation, slope, aspect and curvature.

- Geological: the description of the terrain composition through lithology and geology.

- Geomorphological: the distance from faults and from ravines edges and the seismic risk level.

- Anthropogenic: the distance from roads and land use.

- Hydrological: the distance from rivers.

- Environmental: rainfalls.

Some of the layers, useful for the analysis, have been downloaded from the Lombardy Geoportal [32] as shapefiles, all in the WGS84 UTM Zone 32N reference system.

Also from the same portal, it has been decided to download a layer of the landslide inventory in the Province of Bergamo. This inventory has been collected thanks to the so called IFF project [33]-[38] performed by ISPRA (The Superior Institute for Protection and Environmental Research) and all the Italian regions in the year 2000 .

As for Lombardy, the project involved the region techniques, Universities and research institutions; the number of recorded landslides events amounts to about 144.000 in Italy, 1327 of which in the Province of Bergamo.

The rainfall analysis has been developed starting with the download of meteorological sensors data from the Lombardy ARPA (Regional Agency for the Environment Protection) website [39] and it will be described thoroughly later.

\section{Data Management}

Thanks to many studies in landslides, deeply analyzed here [40]-[45], it has been 
learnt that these phenomena are strictly related to the terrain morphology, i.e. height, aspect and slope; geology, i.e. clay, limestone, gravel and sandstone; hydrology, i.e. distance from rivers; soil texture, i.e. grain size; distance from faults and ravines edges, i.e. terrain fractures and man excavations; land use, i.e. deforestation due to croplands, woods use and cattle breeding; distance from roads, i.e. traffic vibrations and rainfalls; the seismic risk level. All the useful layers for data processing, as previously said, have been downloaded from the Lombardy Geoportal.

\subsection{The Rainfall Map}

The rainfall amount has been the only not available information in the Geoportal and, for this reason, it has required a long selection, collection and processing work, at last providing a raster map useful for the final processing. Hereafter the long procedure is schematized in steps:

- selection of a suitable number of ARPA Lombardia [46] meteorological stations, equipped with pluviometers (Figure 6), well spread in the Province of Bergamo area and the surrounding zones belonging to other Lombardy provinces;

- selection of a number of stations, between 20 and 30 for each year in the 2007-2016 decade, well distributed over the Province of Bergamo and neighboring areas;

- downloading of the rainfall data [47], for each selected station, in the decade just mentioned. These data are in csv Excel format and recorded on a daily basis;

- excel data processing to perform the annual rainfall media, for each station, only if the data have not been missing for more than 30 days in a year;

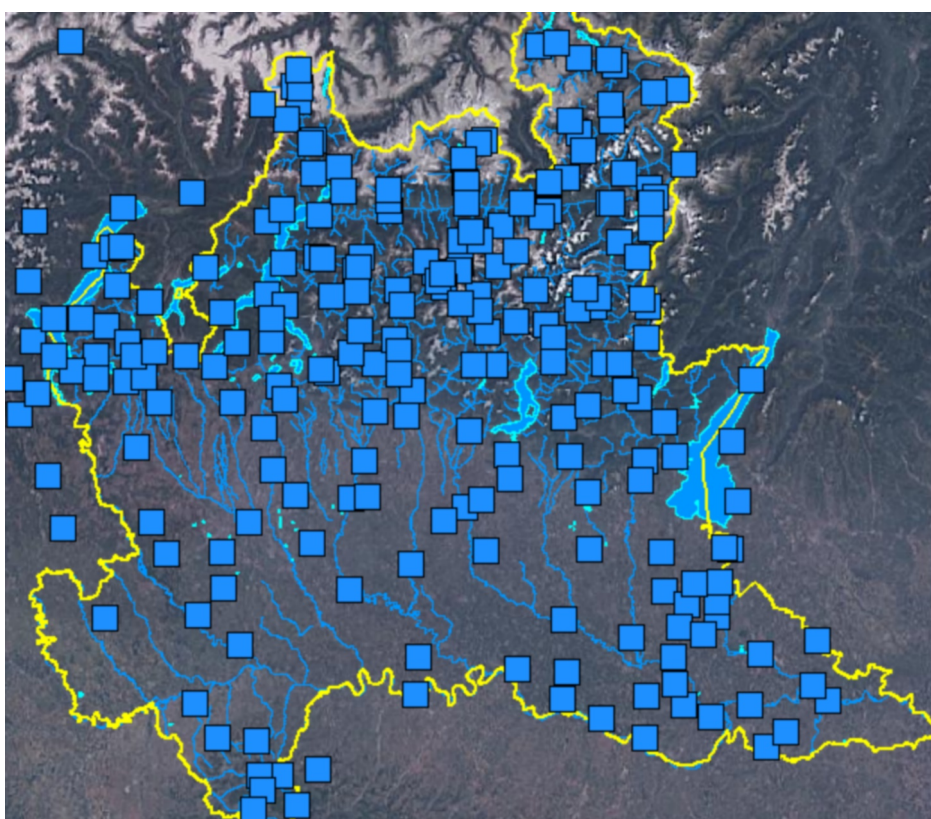

Figure 6. The ARPA Lombardia meteo stations in Lombardy with pluviometers [48]. 
- processing of the selected data in Esri [49] ArcGIS ArcMap 10.4, providing shapefiles in WGS84 UTM zone $32 \mathrm{~N}$ reference system, for each station and for each of the ten selected years, displaying them and listing the corresponding rainfall values;

- interpolation of these data with the Interpolation Spatial Analyst tool, selecting the IDW technique. The better choice would have been between Splines and IDW, but from literature IDW seems to provide a little better results than Splines [50]-[55];

- the ten achieved raster layers, at $10 \times 10$ resolution, showing rainfalls in a region larger than the Province of Bergamo, have then been clipped, through the Spatial Analyst Tool, Extract by Mask, with the aid of the province of Bergamo area shapefile. This step has been necessary, since the raster interpolation has provided layers by interpolating data of meteorological stations distributed in an area wider than the Province of Bergamo;

- the last processing step has performed a simple media operation, with the tool Spatial Analyst Map Algebra, among the ten layers, providing the final raster map of rainfalls in the decade 2007-2016 in the Province of Bergamo (Figure 7).

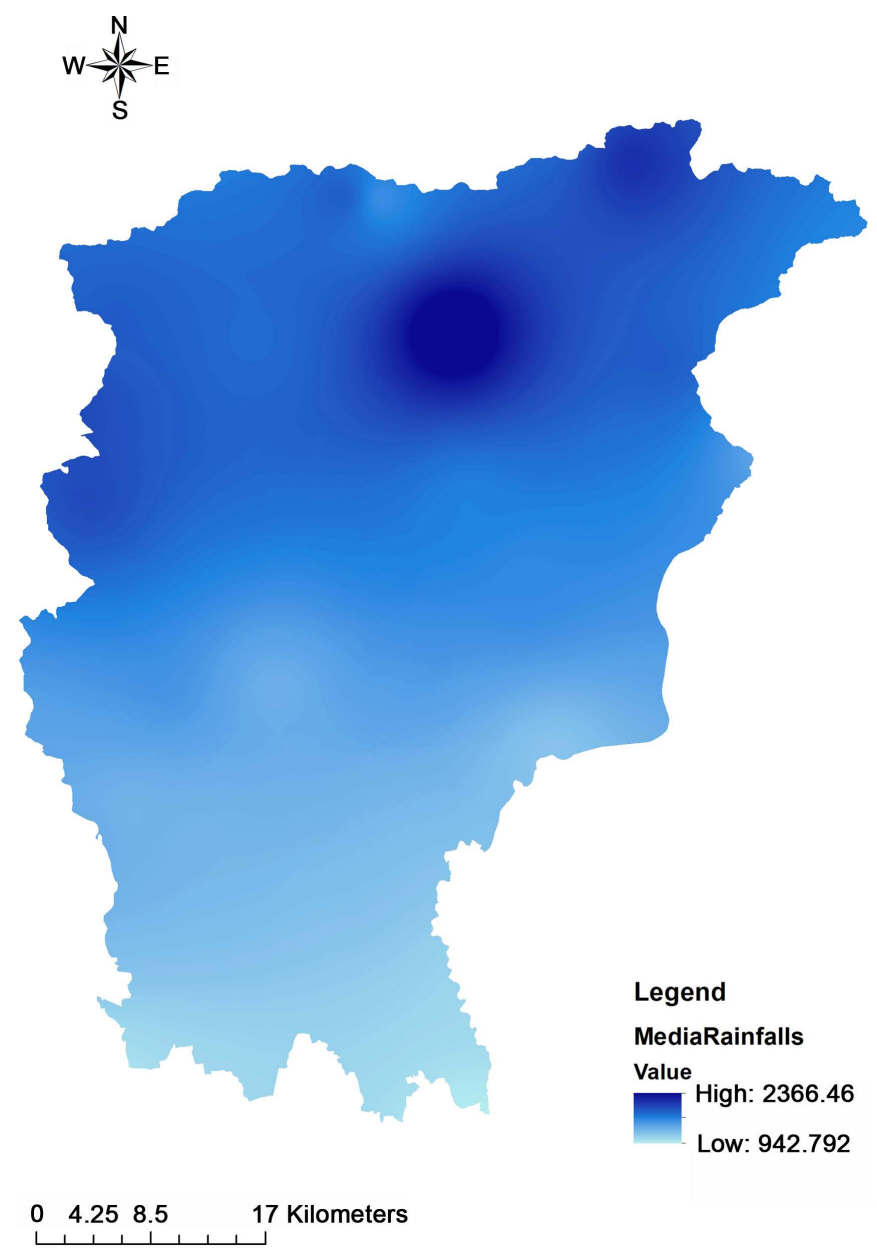

Figure 7. The raster map of rainfalls in the decade 2007-2016 in the province of Bergamo. 


\subsection{Shapefiles Geoprocessing}

In this step, the ArcGIS tool multiple ring buffer has allowed to create buffer areas around the features rivers, roads and ravine edges, according to the selected distances $100 \mathrm{~m}, 200 \mathrm{~m}, 300 \mathrm{~m}$ and $400 \mathrm{~m}$.

\subsection{Raster Layers Selection, Adjusting and Reclassification}

First of all, it has been decided to use the IFFI point shapefile, displaying all the so called historical landslides in the Province of Bergamo, amounting to 1327 events.

As said previously, this shapefile point layer has been downloaded from the Lombardy Geoportal and it lists the landslide inventory in the Province of Bergamo, which has been collected thanks to the so called IFFI project [33]-[38] performed by ISPRA (The Superior Institute for Protection and Environmental Research) and all the Italian regions in the year 2000, so as to provide a national landslide inventory. The number of recorded events amounts to about 144.000 in Italy, 1327 of which in the Province of Bergamo.

Visualizing the spread of the lFFI points, just opening this point layer in ArcMap, together with other shapefile layers (i.e. the faults and curvature layers), it also has been decided to discard, for the final analysis, the distance from faults layer, since all the displayed landslides were located at a very far distance (estimated with the tool measure) from the faults identified in the Province of Bergamo. Also the curvature layer, derived from the DEM layer with the ArcGIS Spatial Analyst Surface Curvature Tool, has been discarded since the IFFI points were almost nearly equally divided over the convex and concave areas; this evaluation has been carried out with the ArcGIS Spatial Analyst Tool Extract values to points, which allowed to count the number of events falling in the two areas.

It has to be also explained that the seismic risk layer, adopted here, is provided by the Integrated Regional Program of Risk Mitigation (PRIM) which points out all the different kind of natural and/or anthropic risk in the Lombardy region. As a matter of fact, generally speaking, according to the seismic risk classes adopted in Italy (they are 4 and 1 is the most dangerous), the Province of Bergamo commons all belong to class 3, i.e. law seismic level. For this reason, at first, the idea had been not to take into account this factor, but the PRIM layer has provided a new kind of classification in Lombardy, showing areas, in the Province of Bergamo, which are more vulnerable than others to earthquakes, and for this reason it has been considered as a main cause in the landslide risk level assessment.

Besides, all the shapefiles have been converted to raster ones at the same $10 \mathrm{x}$ 10 cell size as the rainfall map.

According to what just said, the final selected layers are listed here: DEM Height, Aspect, Slope, Geology, Land Use (Corine 2000), Rainfall, Seismic Risk, Soil texture, Distance from rivers, Distance from roads and Distance form ravines edges. 
These are all raster layers related to the Province of Bergamo territory in WGS84 UTM Zone $32 \mathrm{~N}$ coordinate system and at the same resolution.

At this point, all these files have been reclassified, according to some selected parameters, or range of values, as illustrated in (Table 1 and Table 2).

\section{Landslides Frequency Factor Class Assessment}

As for the Landslides Frequency Factor class assessment, it has been decided to evaluate the number of the landslides, recorded in the IFFI inventory layer in the Province of Bergamo territory (1327), falling inside each class of the reclassified raster layers.

The ArcGIS Spatial Analyst Tool Extract values to points have allowed performing the analysis, counting the number of events for all the raster layers classes. In fact, this command extracts the cell values of a raster based on a set of point features and records the values in the attribute table of an output feature class.

It has then been decided to set the values assigned to the Landslide Frequency Factor as illustrated in Table 3.

Each raster layer has then been reclassified according to the Landslide Frequency Factor.

Table 1. The reclassification selected parameters.

\begin{tabular}{cc}
\hline Layer & Reclassification attribute \\
\hline Distance from roads & Buffer distance \\
Distance from rivers & Buffer distance \\
Distance from ravines hedges & Buffer distance \\
Geology & Lithology \\
Seismic hazard & Seismic risk class $(1 \div 4)$ \\
Land Use (Corine 2000) & LIVELLO1 (LEVEL1) \\
Soil Map & Soil Texture
\end{tabular}

Table 2. The DEM height, aspect, slope and rainfalls selected parameters.

\begin{tabular}{cccc}
\hline DEM height $(\mathrm{m})$ & Slope $^{\bullet}$ & Aspect $^{\bullet}$ & Rainfalls Amount (mm) \\
\hline $0-500$ & $0-15$ & -1 (Flat areas) & $0-942.792$ \\
$500-1000$ & $15-30$ & $0-67.5(\mathrm{~N} / \mathrm{NE})$ & $942.792-1200$ \\
$1000-1500$ & $30-45$ & $67.5-112.5(\mathrm{E})$ & $1200-1400$ \\
$1500-2000$ & $45-60$ & $112.5-157.5(\mathrm{SE})$ & $1400-1600$ \\
$2000-2500$ & $>60$ & $157.5-202.5(\mathrm{~S})$ & $1600-1800$ \\
$>2500$ & & $202.5-247.5(\mathrm{SW})$ & $1800-2000$ \\
& & $247.5-292.5(\mathrm{~W})$ & $>2000$ \\
& & $292.5-360(\mathrm{NW} / \mathrm{N})$ &
\end{tabular}


Table 3. The four adopted landslide frequency factor classes.

\begin{tabular}{cc}
\hline Landslides Amount & Landslides Frequency Factor \\
\hline 0 (included) - 200 (included) & 1 \\
$200-400$ (included) & 2 \\
$400-600$ (included) & 3 \\
$>600$ & 4 \\
\hline
\end{tabular}

Besides, it has also been recorded, for each layer, the highest number of events, i.e. the highest value corresponding to all the 4 Frequency Factor assigned to each raster.

\section{The Risk Model}

The final raster processing has been performed with the Spatial Analyst Map Algebra ArcGIS Tool, as explained in Equation (1):

$$
\text { Landslide Risk }=\sum_{i=1}^{11} a_{i} * \text { Reclassified } \text { Raster }_{i}
$$

The landslides risk model adopted here, is function of all the 11 reclassified raster layers (i.e. Reclassified DEM Height, Reclassified Slope, Reclassified Aspect, Reclassified Land Use, Reclassified Distance from Rivers, Reclassified Distance from Roads, Reclassified Distance from Ravines edges, Reclassified Geology, Reclassified Soil Map, Reclassified Seismic Risk, Reclassified Rainfalls Map) which are summed together, in the Raster Calculator, after having been conveniently multiplied by a coefficient from $a_{1}$ to $a_{11}$. These coefficients have been calculated, in a simple way, for each layer, through a ratio between the highest number for the 4 Frequency Factor previously recorded and the total number of the inventory landslides in the Province of Bergamo (1327), as illustrated in Table 4 .

The result of Equation (1) is illustrated in Figure 8.

This layer has been finally reclassified as described in Table 5, by assigning a Risk Factor from Low (1) to Very High (4), and it is illustrated in Figure 9.

The selected landslide risk evaluation model is quite simple, if compared to more rigorous studies which provide solutions with the aid of statistic laws, but it has been decided that this could be a good and fast compromise.

\section{The Risk Model Validation}

So as to assess the acquired results, illustrated in the landslide Risk Map of the Province of Bergamo, it has been decided to download, from the Lombardy Geoportal, a new layer of the geological studies, carried out by the Commons in the Province of Bergamo. This layer records PAI (Plan of Hydrogeological Layout) instabilities, such as avalanches, landslides, floodings, etc. and it is frequently updated; for this reason, it could be useful to check how many of the landslide events (1775) here recorded, happen to be located in the areas previously classified at High or Very High Risk (Figure 9). 


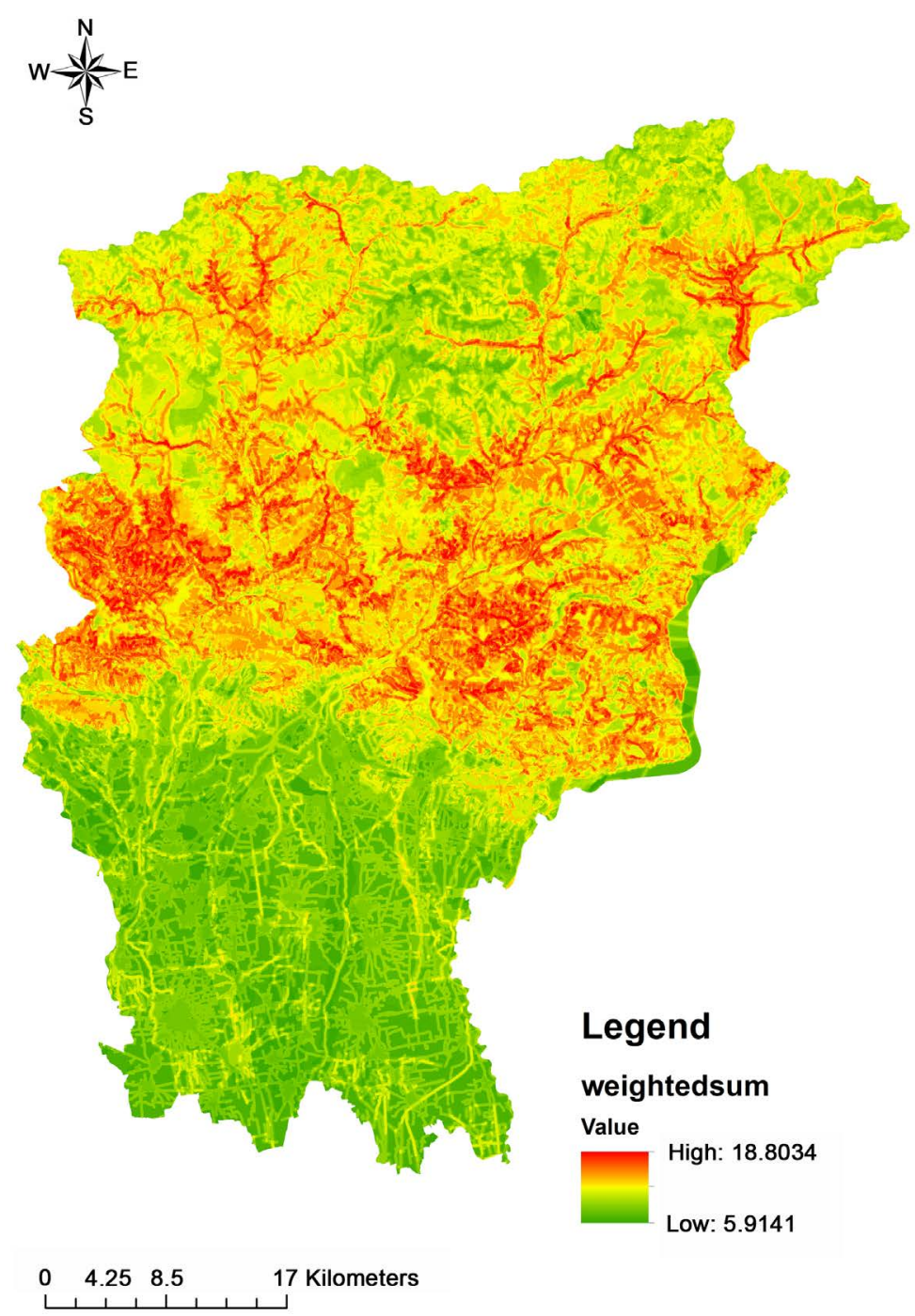

Figure 8. The weighted sum of the reclassified raster layers.

Table 4. The coefficients evaluation.

\begin{tabular}{cc}
\hline Reclassified Raster Layer & Coefficients Evaluation Number \\
\hline DEM Height & $a_{1}=723 / 1327=0.5448$ \\
Slope & $a_{2}=568 / 1327=0.4280$ \\
Aspect & $a_{3}=242 / 1327=0.1824$ \\
Land-Use & $a_{4}=907 / 1327=0.6835$ \\
Distance form Rivers & $a_{5}=927 / 1327=0.6986$ \\
Distance from Roads & $a_{6}=894 / 1327=0.6737$ \\
Distance from Ravines Edges & $a_{7}=641 / 1327=0.4830$ \\
Geology & $a_{8}=293 / 1327=0.2208$ \\
Soil Map & $a_{9}=772 / 1327=0.5818$ \\
Seismic Risk & $a_{10}=412 / 1327=0.2366$ \\
Rainfalls Map & $a_{11}=602 / 1327=0.4537$
\end{tabular}




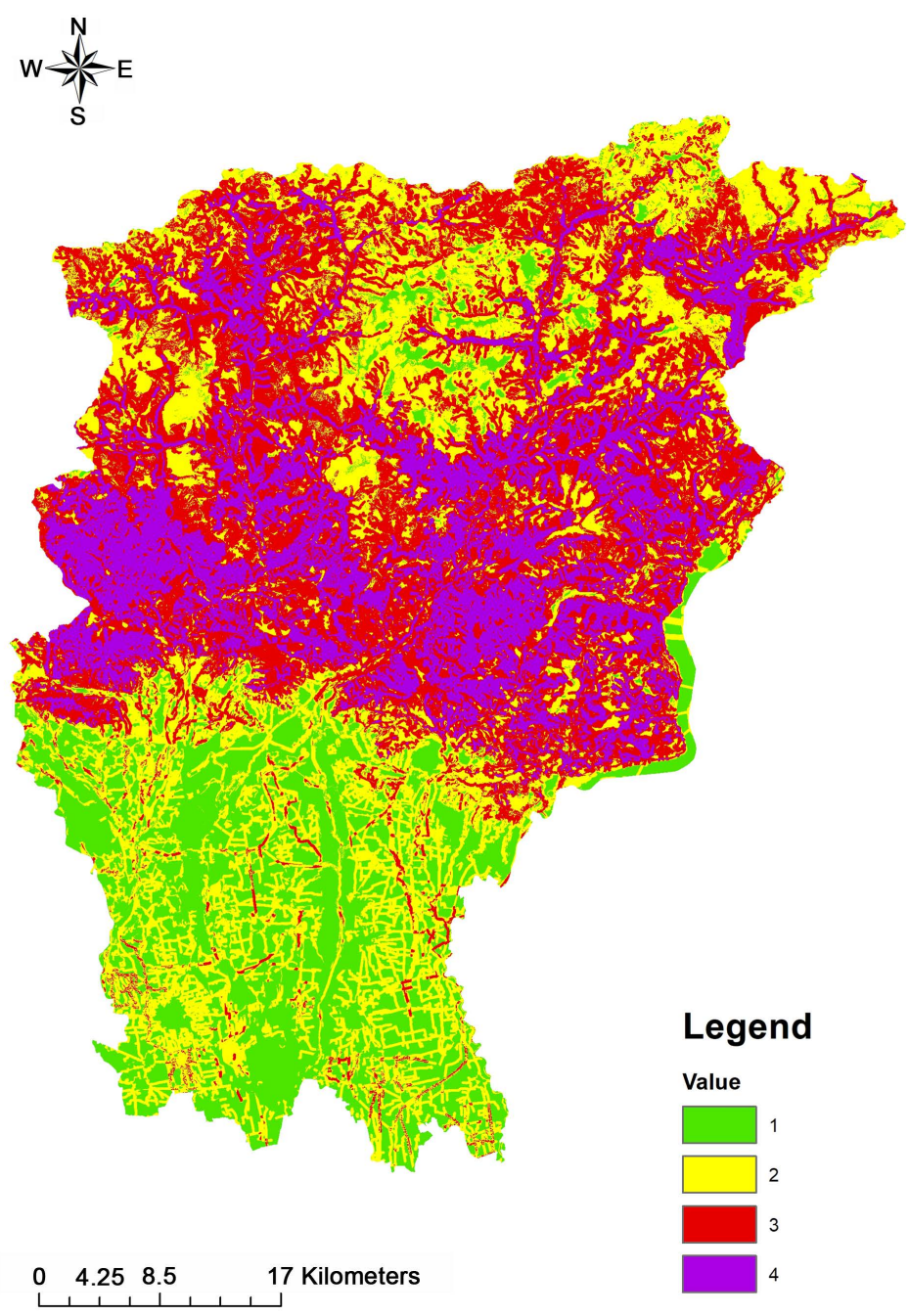

Figure 9. The developed landslide risk map for the province of Bergamo.

Table 5. The four risk factor levels identified for each risk class.

\begin{tabular}{cc}
\hline The Achieved Risk Classes & Risk Factor \\
\hline $12-18$ & Low (1) \\
$18-24$ & Moderate (2) \\
$24-30$ & High (3) \\
$30-36$ & Very High (4) \\
\hline
\end{tabular}

By analysing how these points display over the Province of Bergamo territory, since they fall inside 68 of the 242 commons, it has been decided to choose, as test areas, the Gandino, Mezzoldo and Vilminore of Scalve commons (Figure 10), because of the higher number of events falling inside (Table 6).

To accomplish this task, a point density map has been constructed, with the Spatial Analyst Density tool, Point Density and it is illustrated in Figure 11.

The distribution of these events in the Very High and High Risk zones previously identified is illustrated in Table 7 . 


\section{The three test commons in the Province of Bergamo.}

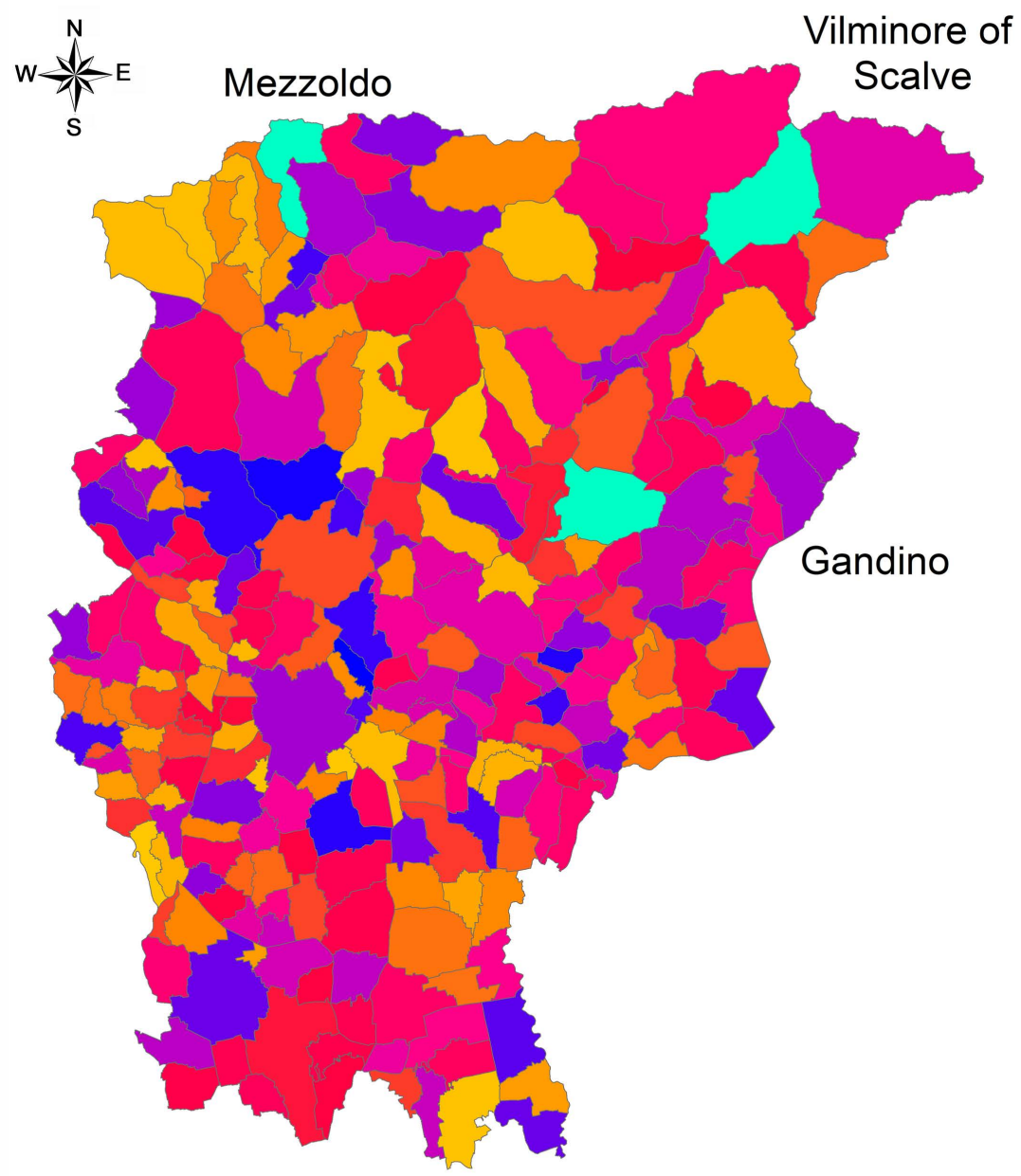

$$
\begin{array}{llll}
0 & 4.25 & 8.5 & 17 \text { Kilometers }
\end{array}
$$

Figure 10. The three selected commons in the province of Bergamo.

Table 6. The three selected commons to test.

\begin{tabular}{cc}
\hline Commons selected & Number of landslides \\
\hline Gandino & 107 \\
Mezzoldo & 519 \\
Vilminore of Scalve & 107 \\
\hline
\end{tabular}

Table 7. The test results.

\begin{tabular}{ccc}
\hline Commons Selected & $\begin{array}{c}\text { Number of Landslides in } \\
\text { Very High Risk Zones }\end{array}$ & $\begin{array}{c}\text { Number of Landslides in } \\
\text { High Risk Zones }\end{array}$ \\
\hline Gandino & 76 & 29 \\
Mezzoldo & 108 & 265 \\
Vilminore of Scalve & 73 & 31 \\
\hline
\end{tabular}


Point density in the Province of Bergamo commons.

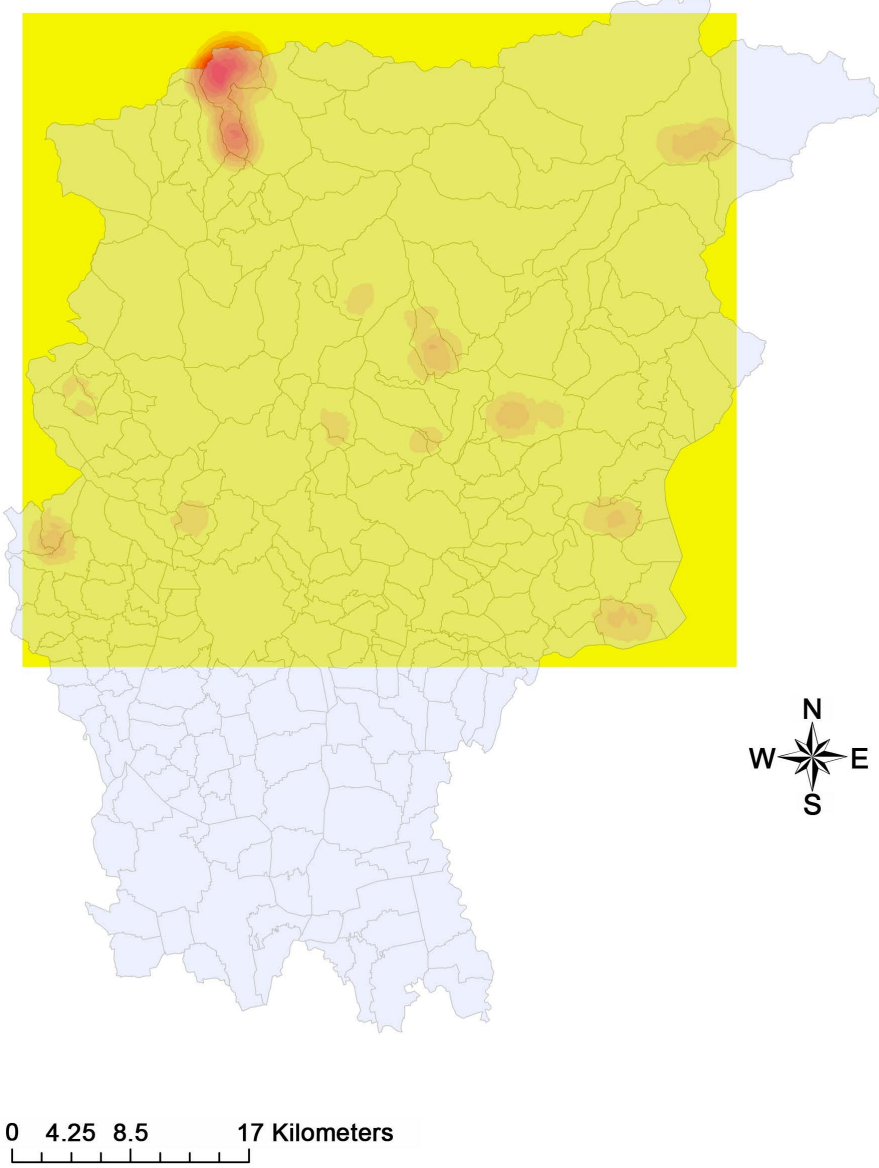

Figure 11. The landslide point density in the province of Bergamo commons.

According to the achieved and satisfying results, the model shows to work quite well in the territory of the Province of Bergamo, so as providing a solid basis on which to plan future developments.

\section{Final Remarks and Future Development}

Landslides Risk Assessment is a very up to date problem which really needs to be studied with great attention.

This paper describes a study experience at the University of Bergamo, which has allowed achieving satisfying results, despite its simplified and not rigorous approach.

The fast application has provided results which are of great help so as to keep monitored the areas at higher risk, but it has to be noticed that this could be considered a first approach to be followed by more precise ones.

Anyway, this is quite a difficult problem to analyse, since it involves many causes which must be investigated in the territory under examination. In fact, generally speaking, many landslides triggering factors work for different geographical situations, but it is always better to investigate if other factors play an important role in the area object of study. 
Obviously, many other factors could have been taken into account here, but the final choice has provided satisfactory results.

As previously said, this risk model, with these weights, works well for the territory of the Province of Bergamo, but if just anything should change, i.e. soil texture, soil disruption, rainfalls, etc., it would require a new estimation of the best fitting multipliers, so as achieving different results.

It could be useful to project a real time risk model, where weights would adjust according to the scenario changing situation.

A future analysis could help to identify residential areas, infrastructures and natural elements (i.e. lakes, rivers, etc.) at risk, since falling inside the high and very high zones.

It could also be possible to simulate a landslide event happening somewhere and then to evaluate the best routes for a fast first aid and firemen intervention.

\section{Acknowledgements}

Thanks for his contribution are due to the GIS course student, at the University of Bergamo (Engineering), Roberto Lo Giudice and to the work developed for his degree thesis.

\section{References}

[1] http://www.today.it/cronaca/frane-alluvioni-italia-zone-a-rischio.html

[2] http://www.corriere.it/esteri/17_settembre_01/frana-svizzera-migliaia-frontalieri-bl occati-d6fe0586-8eea-11e7-b732-dcafc24bf9d5.shtml

[3] http://www.ansa.it/sito/notizie/topnews/2017/08/23/frana-in-svizzera-100-evacuati 98319f70-9e08-431b-9825-19aeb42c7253.html

[4] http://milano.repubblica.it/cronaca/2017/08/23/news/svizzera_frana_svizzera_val_b regaglia_al_confine_con_la_lombardia-173694901/?refresh_ce

[5] http://www.adnkronos.com/fatti/esteri/2017/08/23/gigantesca-frana-confine-tra-ital ia-svizzera-sfollati_T4MEA0HtnFIlIjFj7KKzXL.html?refresh_ce

[6] http://www.rsi.ch/news/ticino-e-grigioni-e-insubria/Crolla-la-montagna-in-Bregagl ia-9463450.html

[7] http://www.meteoweb.eu/foto/frana-in-val-bregaglia-riprese-le-ricerche-degli-8-dispe rsi-non-abbiamo-notizie-da-48-ore-piu-passa-il-tempo-e-piu-difficile-sara-trovarlivivi/id/954968/\#3

[8] http://www.meteoweb.eu/foto/frana-al-confine-tra-italia-e-svizzera-gli-8-dispersi-d ilaniati-dalla-montagna-altri-3-morti-nelle-ultime-ore/id/955773/\#1

[9] http://www.ilgiorno.it/sondrio/cronaca/frana-mera-1.3352327

[10] Catani, F., Lagomarsino, D., Segoni, S. and Tofani, V. (2013) Landslide Susceptibility Estimation by Random Forests Technique: Sensitivity and Scaling Issues. Natural Hazards and Earth System Sciences, 13, 2815-2831. https://doi.org/10.5194/nhess-13-2815-2013

[11] Dou, J., Tien Bui, D., Yunus, A.P., Jia, K., Song, X., Revhaug, I., Xia, H. and Zhu, Z. (2015) Optimization of Causative Factors for Landslide Susceptibility Evaluation Using Remote Sensing and GIS Data in Parts of Niigata, Japan. PLoS ONE, 10, e0133262. https://doi.org/10.1371/journal.pone.0133262 
[12] Costanzo, D., Rotigliano, E., Irigaray, C., Jiménez-Perálvarez, J.D. and Chacón, J.C. (2012) Factors Selection in Landslide Susceptibility Modelling on Large Scale Following the Gis Matrix Method: Application to the River Beiro Basin (Spain). Natural Hazards and Earth System Sciences, 12, 327-340.

https://doi.org/10.5194/nhess-12-327-2012

[13] Felicísimo, Á.M., Cuartero, A., Remondo, J. and Quirós, E. (2012) Mapping Landslide Susceptibility with Logistic Regression, Multiple Adaptive Regression Splines, Classification and Regression Trees, and Maximum Entropy Methods: A Comparative Study. Landslides, 10, 175-189. https://doi.org/10.1007/s10346-012-0320-1

[14] Aleotti, P. and Chowdhury, R. (1999) Landslide Hazard Assessment: Summary Review and New Perspectives. Bulletin of Engineering Geology and the Environment, 58, 21-44. https://doi.org/10.1007/s100640050066

[15] Yilmaz, C., Topal, T. and Süzen, M.L. (2011) GIS-Based Landslide Susceptibility Mapping Using Bivariate Statistical Analysis in Devrek (Zonguldak-Turkey). Environmental Earth Sciences, 65, 2161-2178. https://doi.org/10.1007/s12665-011-1196-4

[16] Pourghasemi, H., Pradhan, B., Gokceoglu, C. and Moezzi, K.D. (2013) A Comparative Assessment of Prediction Capabilities of Dempster-Shafer and Weights-of-Evidence Models in Landslide Susceptibility Mapping Using GIS. Geomatics, Natural Hazards and Risk, 2013, 93-118. https://doi.org/10.1080/19475705.2012.662915

[17] Meinhardt, M., Fink, M. and Tünschel, H. (2014) Landslide Susceptibility Analysis in Central Vietnambased on an Incomplete Landslide Inventory: Comparison of a New Method to Calculate Weighting Factors by Means of Bivariate Statistics. Geomorphology, 234, 80-97. https://doi.org/10.1016/j.geomorph.2014.12.042

[18] Lee, S. and Talib, J.A. (2005) Probabilistic Landslide Susceptibility and Factor Effect Analysis. Environmental Geology, 47, 982-990. https://doi.org/10.1007/s00254-005-1228-Z

[19] Irigaray, C., Fernández, T., El Hamdouni, R. and Chacón, J. (2006) Evaluation and Validation of Landslide-Susceptibility Maps Obtained by a GIS Matrix Method: Examples from the Betic Cordillera (southern Spain). Natural Hazards, 41, 61-79. https://doi.org/10.1007/s11069-006-9027-8

[20] Guzzetti, F., Carrara, A., Cardinali, M. and Reichenbach, P. (1999) Landslide Hazard Evaluation: A Review of Current Techniques and Their Application in a Multi-Scale Study. Central Italy. Geomorphology, 1999, 181-216. https://doi.org/10.1016/S0169-555X(99)00078-1

[21] Devkota, K.C., Regmi, A.D., Pourghasemi, H.R., Yoshida, K., Pradhan, B., Ryu, I.C., et al. (2013) Landslide Susceptibility Mapping using Certainty Factor, Index of Entropy and Logistic Regression Models in GIS and Their Comparison at Mugling-Narayanghat Road Section in Nepal Himalaya. Natural Hazards, 65, 135-165. https://doi.org/10.1007/s11069-012-0347-6

[22] Dou, J., Qian, J., Zhang, H., Chen, S., Zheng, X., Zhu, J., et al. (2009) Landslides Detection: A Case Study in Conghua City of Pearl River Delta. Second Int Conf Earth Obs Glob Chang, 74711K-11.

[23] Nolasco-Javier, D., Kumar, L. and Tengonciang, A.M.P. (2015) Rapid Appraisal of Rainfall Threshold and Selected Landslides in Baguio, Philippines. Natural Hazards, 78, 1587-1607. https://doi.org/10.1007/s11069-015-1790-y

[24] Ahmed, B. (2014) Landslide Susceptibility Mapping using Multi-Criteria Evaluation Techniques in Chittagong Metropolitan Area, Bangladesh. Landslides. https://doi.org/10.1007/s10346-014-0521-x 
[25] https://oggiscienza.it/2011/10/25/litalia-un-paese-fragile/

[26] http://tg24.sky.it/cronaca/2017/09/11/alluvioni-frane-dissesto-idrogeologico-italia.h $\underline{\mathrm{tml}}$

[27] http://www.provincia.bergamo.it/Provpor/portalProcess.jsp

[28] http://www.provincia.bergamo.it/provpordocs/PIANO\%20EMERGENZA\%20PRO VINCIALE\%20RISCHIO\%20FRANE.pdf

[29] http://sit.provincia.bergamo.it/sitera3/ot/navigazione/descrizione.asp?id=1291\&the Browser

[30] http://www.italyheritage.com/genealogy/surnames/regions/lombardia/

[31] https://it.wikipedia.org/wiki/File:Province_of_Bergamo_SRTM.png

[32] http://www.geoportale.regione.lombardia.it/

[33] https://www.sciamlab.com/opendatahub/dataset/r_lombar_nazr-mczz

[34] http://www.isprambiente.gov.it/it/progetti/suolo-e-territorio-1/iffi-inventario-dei-fe nomeni-franosi-in-italia

[35] https://sicurezza.servizirl.it/web/prevenzione-rischi/geoiffi

[36] http://annuario.isprambiente.it/entityada/basic/6211

[37] https://www.dati.lombardia.it/Protezione-Civile/Progetto-IFFI-Inventario-dei-Feno meni-Franosi-in-L/nazr-mczz/data

[38] https://www.dati.lombardia.it/Protezione-Civile/Progetto-IFFI-Inventario-dei-Feno meni-Franosi-in-L/nazr-mczz

[39] http://www.arpalombardia.it/Pages/ARPA_Home_Page.aspx

[40] Pourghasemi, H.R., Pradhan, B., Gokceoglu, C. and Moezzi, D. (2012) Landslide Susceptibility Mapping using a Spatial Multi Criteria Evaluation Model at Haraz Watershed, Iran. In: Pradan, B. and Buchroitner, Eds., Tarrigenous Mass Movements, Springer-Verlag, Berlin Haidelberg.

[41] Perotto-Baldiviezo, H.L., Thurow, T.L., Smith, C.T., Fisher, R.F. and Wu, X.B. (2003) GIS-Based Spatial Analysis and Modelling for Landslide Hazard Assessment in Steeplands, Southern Honduras. Agriculture Ecosystems \& Environment, Elsevier.

[42] Chau, K.T., Sze, Y.L., Fung, M.K., Wong, W.Y., Fong, E.L. and Chan, L.C.P. (2004) Landslide Hazard Analysis for Hong Kong using Landslide Inventory and GIS. Computer \& Geosciences, Elsevier.

[43] Van Westen, C.J., Castellanos, E. and Kuriakose, S.L. (2008) Spatial Data for Landslide Susceptibility, Hazard, and Vulnerability Assessment: An Overview. Engineering Geology, Elsevier.

[44] Shababi, H. and Hashim, M. (2015) Landslide Susceptibility Mapping Using GIS-Based Statistical Models and Remote Sensing Data in Tropical Environment. Scientific Reports.

[45] Chalkias, C., Ferentinou, M. and Polykretis, C. (2014) GIS-Based Landslide Susceptibility Mapping on the Peloponnese Peninsula, Greece. Geosciences, 4, 176-190. https://doi.org/10.3390/geosciences4030176

[46] http://www.arpalombardia.it/siti/arpalombardia/meteo/osservazioniedati/datitemp oreale/rilevazioni-in-tempo-reale/Pagine/Rilevazioni-in-tempo-reale.aspx

[47] http://www.arpalombardia.it/siti/arpalombardia/meteo/richiesta-dati-misurati/Pagi ne/RichiestaDatiMisurati.aspx

[48] http://idro.arpalombardia.it/pmapper-4.0/map.phtml 
[49] http://www.esri.com

[50] Noori Mohamad, J., Hassan, H. and Yaseen, M. (2014) Spatial Estimation of Rainfall Distribution and Its Classification in Duhok Governorate using GIS. Journal of Water Resource and Protection, 6, 75-82. https://doi.org/10.4236/jwarp.2014.62012

[51] Chen, F.W. and Liu, C.W. (2012) Estimation of the Spatial Rainfall Distribution using Inverse Distance Weighting (IDW) in the Middle of Taiwan. Paddy and Water Environment, 10, 209. https://doi.org/10.1007/s10333-012-0319-1

[52] Yang, X., Xie, X., Liu, D., Ji, F. and Wang, L. (2015) Spatial Interpolation of Daily Rainfall Data for Local Climate Impact Assessment over Greater Sydney Region. Advances in Meteorology, 2015, Article ID: 563629.

[53] Basistha, A., Arya, D.S. and Goel, N.K. (2008) Spatial Distribution of Rainfall in Indian Himalayas-A Case Study of Uttarakhand Region. Water Resources Management, 22, 1325. https://doi.org/10.1007/s11269-007-9228-2

[54] Dirks, K.N., Hay, J.E., Stow, C.D. and Harris, D. (1998) High-Resolution Studies of Rainfall on Norfolk Island: Part II: Interpolation of Rainfall Data. Journal of $\mathrm{Hy}$ drology, 208, 187-193. https://doi.org/10.1016/S0022-1694(98)00155-3

[55] Romeo, R.W., Tiberi, P., Floris, M., Mari, M., Perugini, M., Pappafico, G. and Veneri, F. (2006) Indagine sui rapporti esistenti tra uso del suolo e dissesto idrogeologico nella Regione Marche. Giornale di Geologia Applicata, 4, 253-256. 